\title{
水利工程施工中软土地基处理技术分析
}

\author{
李恩祥 \\ 吉林省洮南市河道堤防管理站 \\ DOI:10.32629/btr.v3i1.2835
}

[ 摘 要] 在水利工程施工建设中,需要认识到软土地基在其中发挥的作用。软土地基作为影响水利工程施工质量的重要部分,将会给水利工程 今后发展带来影响。本文就结合软土地基基本特点,对水利工程软土地基处理要求进行分析,并以此为依据,提出水利工程施工中软土地基处理 技术,具体如下。

[关键词] 水利工程; 软土地基; 处理技术

在开展水利工程施工工作时, 相关人员应结合水利工程施工特点, 参 考施工标准, 对软土地基进行统一处理, 这样能够并把水利工程施工建设 中不利影响因素降至最小, 在提升水利工程施工效率的同时, 也能保证水 利工程施工质量, 对促进水利工程行业发展有着重要意义。

\section{1 软土地基基本特点概述}

1. 1 沉降几率大

因为软土地基自身具备强度低、密度小等特点, 因此在工程量逐渐增 多的情况下, 发生地基沉降几率比较大。在此过程中需要注意, 随着承载力 不断升高, 沉降效率将逐渐加快。

\section{2透水能力差}

软土地基具备的另一个特点在于透水能力差, 因此在水利工程施工建 设之前, 需要做好软土地基排水工作, 适当提升软土地基稳定性 ${ }^{[1]}$ 。但是在 此过程中, 需要投放大量资源, 使得水利工程建设周期受到影响。

\section{3压实性能强}

因为软土地基自身具有松软特点, 因此压缩性能强, 同时强度比较低。 在开展水利工程施工建设工作时, 如果没有对软土地基及时处理, 随着其 承载力的增加, 使得塌陷现象出现, 无法保证水利工程整体质量安全。

\section{2 水利工程软土地基处理要求}

2. 1 质量要求

在水利工程施工建设中, 大部分的地基为软土地基, 因此在软土地基 施工过程中, 做好地基处理工作, 才能保证工程质量满足国家要求。现阶段, 水利工程在应用途径上比较多样, 对应的建设要求也会存在差异, 因此在 实际建设过程中, 应该结合实际情况, 加强软土地基处理, 并非按照统一要 求进行。通过综合思考各种因素, 实现软土地基处理, 可以降低对水利工程 施工建设的影响, 保证工程质量安全。

\section{2 工期要求}

在进行水利工程施工时, 需要根据水利工程建设要求进行, 作为施工 进度的主要标准之一, 建设周期起到了重要意义。因此, 在施工之前, 应到 施工现场进行实地考察, 制定可行性施工计划 ${ }^{[2]}$ 。在施工建设中, 严格按照 计划要求操作, 降低因为工期延误而给施工质量带来的影响。在具体施工 过程中, 应该结合工程进度情况进行软土地基处理, 在保证施工质量的情 况下, 缩短施工期限, 确保工程日期完工。

\section{3 水利工程施工中软土地基处理技术}

3. 1 强夯处理技术

在水利工程施工建设中, 比较常见的软土地基主要以黄土与砂土混合 形式为主, 所以在施工过程中, 需要适当提高地基强度。强夯施工技术在这 种地基中可以发挥一定效果。强夯粗粒技术主要是在夯锤的作用下进行土 层夯实处理, 有效提高地基密度, 从而达到夯实目的。在应用强夯处理技术
过程中, 需要根据水利工层建设地基实际情况和地基组成成分, 设计具 体施工方案, 结合工程情况明确施工要求, 如果地基为重砂及细砂土组 成的软土地基, 在强夯过程中, 夯锤单次打击力度需要控制在 $300 \mathrm{kN}$ 左右, 同时保证夯击的持续性 ${ }^{[3]}$ 。结合夯实频率调整重锤落地距离, 以此获取 理想的夯实效果。在强夯处理技术中, 主要是利用物理性夯实方式, 提升 地基的稳定性, 强化地基密度, 防止在水利工层施工建设过程中发生地 基沉降等问题。

\section{2 预应力管桩技术}

通常情况下, 预应力管桩技术主要适用于管桩施工建设中。在使用预 应力管桩处理技术过程中, 需要注意的内容具体展现在以下几个方面。首 先, 在开展施工工作之前, 应该做好管桩建设位置检查工作, 保证其位置的 合理性和规范性。并且, 时刻关注成品桩质量, 确保成品桩质量满足水利工 程建设要求。其次, 在具体施工建设过程中, 需要合理选择桩基和桩锤, 保 证其满足施工具体要求, 如参考管桩规格、水利工程地基建设土层结构等, 确定管桩入土深度。在全面施工过程中, 严格按照施工设计方案, 做好施工 现场放样工作, 核实施工方案的科学性。在管桩建设过程中, 影噶保证管桩 插入以后垂直度和标准相迎合, 要求施工人员在落实桩插入工作时, 需要 适当调整插入位置, 减少偏差, 把垂直度控制在理想的范畴内。最后, 在接 桩及送桩过程中, 工作要点在于关注焊接的合理性和送桩机选择, 在管桩 施工完成以后, 把施工记录当作凭证, 对管桩整体施工情况进行检查, 避免 存在质量问题。

3. 3 灌浆处理技术

在采用灌浆处理技术过程中, 需要做好前期准备工作, 不但要对施工 现场土层情况和河流特点有深入了解, 同时还要科学设计施工方案, 准备 施工过程中所需的材料及设备, 特别是对材料及设备质量情况进行检查, 保证在施工建设中不会因为受到材料及设备质量因素的影响, 延长施工进 度。在具体施工过程中, 需要关注细节操作, 例如, 灌浆之前的造孔, 结合地 基实际情况, 对钻机型号及钻进方式进行选择。再例如, 灌浆之前应该做好 压水实验工作, 保证钻孔环境满足灌浆要求。在灌浆操作过程中, 应该结合 实际情况进行分段处理, 选择最佳的灌浆方式有序进行。在完成各阶段灌 浆工作以后, 需要及时进行压水实验。此外, 在完成灌浆工作后, 需要及时 进行质量检测, 通过监管钻孔胶结情况, 分析施工参数等了解灌浆质量。灌 浆处理技术应用将会给水利工程施工建设带来直接影响, 需要利用公式计 算出最初参数, 同时结合水利工程实际情况进行多次实验, 明确最终灌浆 压力, 保证施工顺利落实。

3. 4 换填土技术

换填土施工处理技术作为水利工程软土地基施工中比较普遍, 具体施 工内容需要结合地基强度要求, 根据水利工程施工特点和地理条件, 实施 


\title{
用于电梯的计算机远程监控网络系统研
}

\author{
袁嘉艺 \\ 西继迅达(许昌)电梯有限公司 \\ DOI:10.32629/btr.v3i1.2775
}

[摘 要] 近年来,高层住宅以及建筑的数量不断增加, 使电梯在建筑中的应用越来越广泛, 因为电梯会安置在不同的小区,所以电梯具有较广的 地域分布,在这种情况下,传统的人工处理已经不能有效的发挥发现以及处理电梯故障的作用,使相关的管理企业越来越注重如何对电梯进行高 效的维修。随着计算机技术的不断发展,使对电梯进行远程网络监控成为可能,本文将对电梯远程监控网络系统需要具备的功能、组成部分等进 行研究

[关键词]电梯; 计算机; 远程监控

电梯是一种沿着垂直路线运行的交通运输设备, 主要应用于高层建筑, 随着我国逐步加快城市化进程, 在各种住宅以及小区中电梯已经成为了必 不可少的组成部分。但是现阶段大部分的电梯都需要专业的人员进行上门 维修, 但是随着电梯数量的增多以及分布的地域越来越广泛, 使这种传统 的维修方式变得捉襟露肘, 使电梯用户的需求很难得到满足, 所以, 很多电 梯的制造商以及使用企业对应用计算机技术和网络系统远程监控电梯进 行研究。

\section{1 远程监控系统概述}

电梯远程监控系统就是利用电话线或者网络, 使有关人员可以在电梯 维修服务中心, 远程监视以及操作分布在不同地区的电梯, 使维修人员能 够及时的了解电梯的故障情况, 保证维修工作能够得到更加及时、有效的 开展, 使电梯故障对人们的影响得到有效控制 ${ }^{[1]}$ 。

它的设计思路是通过计算机技术, 对不同地区电梯的运行状况进行实 时监控, 能够对电梯的各种故障情况以及运行数据做到自动记录并且保 存。当电梯有故障发生时, 远程监控网络系统中的监视系统会发出警报, 并且相关的负责人员也会接到通知。能够快速的锁定出现故障电梯的地理 位置、型号等信息。管理人员在对电梯故障进行确认后, 能够通知负责故 障发生地区的电梯维修人员, 使故障能够在短时间内得到排除。

\section{2 远程监控系统需要具备的基本功能以及设计原则}

2. 1 远程监控系统需要具备的功能

想要实现远程监控电梯, 监控系统需要具备以下基本功能:

换填土操作, 有效提升水利工程地基稳定性。在使用换填土处理技术过程 中, 需要在相关机械设备配合下进行, 对于不满足水利工程建设要求的软 土进行挖掘, 之后把粗砂等材料填入其中, 对其进行夯实处理, 从而提升地 基强度, 让地基性能满足水利工程施工要求 ${ }^{[4]}$ 。通常情况下, 换填土施工工 艺比较简便, 在水利工程施工建设中应用广泛, 但是其也存在一定局限性, 例如如果施工范畴比较大, 施工量较多, 在人力、物力等资源消耗上比较大, 投放的成本多, 所以该项处理技术自身经济效益不高, 不适合应用在大面 积施工中

\section{5 排水砂垫层处理技术}

排水砂垫层处理方式主要对在对水利工程软土地基处理过程中, 把 一些含水量比较高的土层进行置换和排出处理。在使用该方式过程中, 操作原理较为简便。对砂垫层方式的科学应用, 能够将地基中多余的水 分顺利排出。但是在具体应用中需要注意, 砂垫层主要应用在地基底层 位置的填充, 让地基防水功能得到提高。并且, 在应用该方式时, 需要预 留排水位置, 这样可以将地基的水分快速排出, 提升地基稳定性, 保证工
2. 1.1 实时进行语音报警。

2.1.2 能够对现场的维修人员进行协助, 具备一定分析以及处理故障 的能力。

2.1.3可以对电梯的部分功能进行远程控制。

2.1. 4 对电梯的运行参数进行记录。

2.1.5记录以及统计故障。

2.1. 6 能够保存电梯的维修记录和故障报表, 在需要使能够完成相关 资料的打印。

2.1.7 需要抗干扰能力较强 ${ }^{[2]}$ 。

2. 2 远程监控系统的设计原则

2.2.1可靠性。需要系统拥有极强的适应能力, 能够在恶劣的环境下正 常运行, 并且系统需要具备稳定的性能, 为系统运行的安全可靠提供保障。

2.2.2通用性。因为电梯公司不同, 所以它们研制的电梯远程监控也会 存在差异, 导致各个系统间不能进行兼容, 所以在进行系统设计时, 应该对 使用对象的共性进行充分考虑, 保证系统的通用性较强, 能够在不同种类 的电梯适用。

2.2.3 经济性。远程监控系统需要拥有合理的造价, 较高的性价比。

\section{3 远程监控系统总体方案设计}

电梯远程监控网络系统出了需要应用计算机技术, 还会涉及到通信技 术以及数字电路等方面的知识, 才可以有效的为电梯平稳快速运行提供保 障 $^{[3]}$ 。

程整体质量安全。

\section{4 结束语}

总而言之, 在水利工程施工建设中, 软土地基作为重要内容, 在对软土 地基处理过程中, 需要根据工程具体状况, 做好前期准备工作。与此同时, 根据施工要求, 制定施工方案, 采取一系列处理方式, 提升软土地基强度, 保证水利工程施工质量, 给我国水利工程行业健康发展提供条件。

\section{[参考文献]}

[1]陆启楼.软土地基处理技术在水利施工中的应用 [J].工程技术研 究,2019,4(18):67-68.

[2]钟超文.试论软土地基处理技术在市政路桥工程施工中应用 [J].低 碳世界,2019,9(09):303-304.

[3]李义方.岩土工程施工中软土地基处理的方法与应用研究[J].建筑 技术开发,2019,46(18):141-143.

[4]刘蓂.水利工程施工中软土地基处理方法分析[J].农业科技与信 息,2019,(17):100-101. 